\title{
Protein kinase A serves as a primary pathway in activation of Nur77 expression by gonadotropin-releasing hormone in the LBT2 mouse pituitary gonadotroph tumor cell line
}

\author{
TARIQ HAMID ${ }^{1}$, MOHAMMED T. MALIK ${ }^{1}$, ROBERT P. MILLAR ${ }^{2,3}$ and SHAM S. KAKAR ${ }^{1}$ \\ ${ }^{1}$ Department of Medicine and James Graham Brown Cancer Centre, University of Louisville, Louisville, \\ KY 40202, USA; ${ }^{2}$ MRC Human Reproductive Sciences Unit, Edinburgh, Scotland; ${ }^{3}$ Department of \\ Medical Biochemistry, University of Cape Town, South Africa
}

Received May 15, 2008; Accepted July 1, 2008

DOI: 10.3892/ijo_00000094

\begin{abstract}
Nur77 belongs to a subfamily of nuclear receptors that includes two other members, Nor-1 and Nurr1. It plays an important role in a number of biological processes, including regulation of signaling functions in the hypothalamo-pituitaryadrenal axis, regulation of thymocyte apoptosis, regulation of steroidogenesis and regulation of tumor cell proliferation and apoptosis. In previous studies, using DNA microarray analysis of the effects of the gonadotropin-releasing hormone $(\mathrm{GnRH})$ on the mouse pituitary gonadotroph cell line LBT2, we identified Nur77 as one of the highly regulated immediate early genes involved in this response, with $>40$-fold upregulation after $1 \mathrm{~h}$ of treatment of the cells with the GnRH agonist [D-Ala ${ }^{6} \mathrm{GnRH}$ (GnRHA)]. GnRH is a hypothalamic decapeptide that stimulates the secretion and expression of gonadotropins (follicle stimulating hormone, FSH and luteinizing hormone releasing hormone, $\mathrm{LH}$ ) from anterior pituitary through activation of high affinity receptors present on cell membrane of pituitary gonadotropes. In addition to pituitary, the presence of GnRH high affinity receptors has been reported in various cancers and cancer cell lines. In addition, GnRH and its analogs are clinically used in the treatment of prostate cancer. To elucidate the molecular mechanism involved in regulation of Nur77 by GnRH, we first confirmed upregulation of Nur77 in response to GnRH analog (GnRHA) in LBT2 cells. Nur77 mRNA was upregulated within 30 min of GnRHA treatment and returned to nearly basal level after $24 \mathrm{~h}$ of treatment. Nur77 protein expression was upregulated after $2 \mathrm{~h}$ of treatment and remained steady even after $12 \mathrm{~h}$ of treatment. The expression of Nur77 mRNA was induced by GnRHA in a dose-dependent manner. Induction of Nur77 expression was stimulated on treatment of cells with forskolin and 8-Br-cAMP, whereas $\mathrm{H}-89$, a specific inhibitor of PKA pathway significantly inhibited GnRHAinduced Nur77 expression. Treatment of cells with both H-89
\end{abstract}

Correspondence to: Dr Sham S. Kakar, Department of Medicine, 580 S. Preston Street, Baxter II, Room 324, Louisville, KY 40202, USA

E-mail: sskaka01@louisville.edu

Key words: Nur77, gonadotropin-releasing hormone signaling, protein kinase A, protein kinase C, pituitary, LßT2, cancer and EGTA completely blocked the GnRHA-induced expression of Nur77, indicating that both calcium and cAMP/PKA play an important role in regulation of Nur77 expression by GnRHA. Analysis of the protein kinase $\mathrm{C}$ (PKC) signaling pathway using specific inhibitors for PKC, Erk1/2, p38 and JNK demonstrated that these pathways are not involved in GnRHA-induced Nur77 expression. Based on our results, we conclude that activation of protein kinase $\mathrm{A}$ is the major mechanism regulating the expression of Nur77 by $\mathrm{GnRH}$ which may serve as a down-stream signaling gene to mediate the antitumor effects of $\mathrm{GnRH}$.

\section{Introduction}

Nur77 (also known as NGFI-B or TR3) encodes an orphan nuclear receptor that is expressed in a wide variety of tissues, i.e., the thymus, muscle, liver, thyroid, lung, testis, ovary, ventral prostate, adrenal and pituitary $(1,2)$. It belongs to a subfamily of nuclear receptors that includes two other members, Nor-1 (mitogen-induced nuclear orphan receptor [MINOR], nuclear receptor subfamily 4, group A, member 3 [Nr4a3]) and Nurr1 (transcriptionally inducible nuclear receptor [TINUR], nuclear receptor subfamily 4 , group A, member $2[\mathrm{Nr} 4 \mathrm{a} 2])$. The members of this family are classified as immediate early genes as their expression is rapidly but transiently, induced by serum and growth factors $(3,4)$, as well as various other stimuli involved in cellular differentiation and proliferation $(5,6)$. Expression of Nur77 in endocrine cells is rapidly induced by corticotrophin-releasing hormone (CRH), thyroid-stimulating hormone (TSH), follicle-stimulating hormone (FSH), luteinizing hormone (LH) and adrenocorticotropic hormone (ACTH) (7-10). Previously, Nur77 activation by several apoptosis inducing agents, such as 1,1-Bis(3'indolyl)-1-(p-substituted phenyl)methanes to induce apoptosis in pancreatic cancer cell line (Panc-28) apoptosis has been demonstrated (11).

The domain structure of Nur77 and other family members is that of a classical nuclear receptor structure, with an $\mathrm{N}$ terminal activation function-1 (AF-1) domain, a highly homologous DNA-binding domain (DBD) and a similar ligand-binding domain (LBD), together with a C-terminal activation function-2 (AF-2) domain (reviewed in ref. 12). As a monomer, Nur77 binds to the Nur77-binding response 
element (NBRE), which contains the hexanucleotide sequence AGGTCA, a typical recognition motif of the RAR/RXR family (13). Binding of homodimers of Nur77 to DNA has been shown as well as binding of heterodimers composed of Nur77 and the retenoid $\mathrm{X}$ receptor (14). The regulation of Nur77 expression is not understood fully; however, recent studies indicate that Nur77 is regulated both at the level of transcription and post-translationally. In addition to direct binding of Nur77 to NBRE, its binding also has been demonstrated to be regulated by recruitment of co-activators and co-repressors $(12,15-17)$.

Nur77 has been implicated in a number of biological processes including regulation of signaling functions in the hypothalamo-pituitary-adrenal axis (18-20) and regulation of steroidogenesis by modulating the expression of steroidogenic enzymes (21). In addition, Nur77 has been shown to be involved in T-cell receptor (TCR) mediated apoptosis in immature thymocytes and T-cell hybridomas $(22,23)$, induction of apoptosis in lung cancer cells (24) and prostate cancer cells (25), activation-induced cell death $(11,22,26-28)$ and neuronal differentiation of PC12 cells (29). In contrast to its role as a pro-apoptotic molecule, Nur77 has also been described as a survival factor when induced through tumor necrosis factor signaling (30). A recent report demonstrates that Nur77 can interact with $\mathrm{Bcl}-2$, resulting in conversion of $\mathrm{Bcl}-2$ from an anti-apoptotic to a pro-apoptotic molecule in HEKT and HCT-116 cells (31). Apart from its role in endocrine signaling and apoptosis, Nur77 has also been shown to be involved in tumor progression and metastasis by its stabilization of hypoxia inducible factor- $\alpha(\mathrm{HIF}-1 \alpha)$ (32) and stimulation of proopiomelanocortin (POMC) (7) besides being identified as a key 'signature-gene' involved in metastatic progression of tumors (33) and, previously, Nur77 along with and other family members have been shown to play important roles in cellular transformation and oncogenesis of cervical cancer (34).

High levels of expression of Nur77 have been reported in pituitary (35), but the physiological stimuli that regulate its expression in pituitary remains unknown. In our recent studies, using DNA microarray analysis of mRNA expression of mouse pituitary gonadotroph cells (LBT2) on treatment with gonadotropin-releasing hormone $(\mathrm{GnRH})$ agonist (D-Ala $\left.{ }^{6}\right)$ GnRH (GnRHA), we found an 40 -fold increase in expression of Nur77 mRNA within $1 \mathrm{~h}$ of treatment (36). This finding was consistent with observations made previously by other investigators $(3,4,37,38)$. Gonadotropin-releasing hormone (GnRH) is a hypothalamic decapeptide that is synthesized by hypothalamic neurons and released into the portal circulation in a pulsatile fashion (39). It plays an important role in reproductive physiology by regulating the expression and secretion of FSH and LH. GnRH has also been shown to be involved in regulation of cell proliferation and apoptosis $(40,41)$ and cytoskeletal rearrangements $(42)$. GnRH and its analogs are currently used in the treatment of prostate cancer (reviewed in ref. 43). The present studies were carried out to gain an understanding of the regulation of Nur77 expression by GnRH in LßT2 cells and to decipher the molecular signaling mechanism(s) involved in this regulation. Our results indicate that GnRH transiently activates Nur77 expression and this activation by $\mathrm{GnRH}$ is primarily achieved through the activation of cAMP-PKA signaling pathway.

\section{Materials and methods}

Reagents. GnRH-A ([D-Ala $] \mathrm{GnRH}), 12-\mathrm{O}-$ tetradecanoylphorbol-13-acetate (PMA), H-89, ionomycin, 8-Br-cAMP, GnRH antagonists (Antide) and Forskolin (FSK) were obtained from Sigma (St. Louis, MO). PKC inhibitors BIM-I, BIM-IV and JNK inhibitor SP600125 were purchased from Calbiochem (La Jolla, CA). MEK inhibitor U0126 and p38 inhibitor SB202190 were purchased from Biosource International (Camarillo, CA). Rabbit monoclonal antibodies against Erk1/2, p38 and JNK were obtained from Cell Signaling Technologies (Beverly, MA).

Cell culture. LBT2 cells were maintained in monolayer cultures in DMEM supplemented with $10 \%$ FBS and antibiotics in humidified $5 \% \mathrm{CO}_{2}$ at $37^{\circ} \mathrm{C}(44)$. After $24 \mathrm{~h}$ of plating, the medium was replaced with serum-free medium and incubated for an additional $24 \mathrm{~h}$. The cells were then treated with GnRHA, various activators, or inhibitors as detailed in figure legends.

Isolation of total RNA and reverse transcriptase (RT) PCR. Total RNA from LBT2 cells was purified using Trizol reagent (Invitrogen, Carlsbad, CA) following the manufacturer's instructions. The RNA pellets were resuspended in RNase-free water and any contaminating DNA removed from the preparations by treatment with DNaseI. The yield of total RNA was measured using spectrophotometery and the quality of preparation checked by $1 \%$ agarose. First-strand cDNA was synthesized using the iScript ${ }^{\mathrm{TM}}$ cDNA synthesis kit (Bio-Rad, Hercules, CA), as described previously (45). PCR primers (sense 5'-GTGCTCCTCAGCTTGTTCC-3' and antisense 5'-CTGACACGAAGCATTGTCAC-3') for Nur77 were designed, based on the mouse Nur77 coding sequence. The PCR conditions were: denaturation at $95^{\circ} \mathrm{C}$ for $5 \mathrm{~min}$ followed by denaturation at $95^{\circ} \mathrm{C}$ for $30 \mathrm{sec}$, annealing at $54^{\circ} \mathrm{C}$ for $30 \mathrm{sec}$ and extension at $72^{\circ} \mathrm{C}$ for $30 \mathrm{sec}$ for 30 cycles with the last extension step at $72^{\circ} \mathrm{C}$ for $7 \mathrm{~min}$. Glyseraldehyde-3-phosphate dehydrogenase (GAPDH) amplification was used as an internal control. The primers for GAPDH used were sense 5'-TGATGACATCAAGAAGGT GGT-3' and antisense 5'-TCCTTGGAGGCCATGTGGGCC-3'. A $10 \mu 1$ aliquot from a total of $50 \mu 1$ PCR reaction mix was subjected to $1.5 \%$ agarose gel. The gel was stained with ethedium bromide and destained to visualize PCR products (45). The PCR amplified products were quantified by scanning the ethidium bromide stained bands using Bio-Rad software and normalized against the GAPDH values.

Activation of MAPK cascades and Western blot analysis. LßT2 cells were grown in 6-well plates and starved of serum overnight prior to the experiment, as described above. The cells were pretreated with various inhibitors for $1 \mathrm{~h}$ prior to being treated with $10 \mathrm{nM}$ GnRHA for time periods indicated in the figure legends. The cells were washed twice with icecold PBS and harvested by scraping into $100 \mu 1$ of cold lysis buffer [50 mM Tris- $\mathrm{HCl}$ (pH 7.4), 1\% NP-40, 0.25\% sodium deoxycholate, $150 \mathrm{mM} \mathrm{NaCl}, 1 \mathrm{mM}$ EGTA, $1 \mathrm{mM}$ phenylmethylsulfonyl fluoride, $1 \mu \mathrm{g} / \mathrm{ml}$ aprotinin, $1 \mu \mathrm{g} / \mathrm{ml}$ leupeptin] that was added directly into the wells. The lysates were 
collected and incubated on ice for 5 min before centrifugation to pellet debris. The protein concentration of clarified supernatant was determined using Bradford assay (Bio-Rad). Protein $(40 \mu \mathrm{g})$ from each sample was fractionated by $10 \%$ SDS-PAGE and electroblotted onto Hybond nitrocellulose (Amersham Biosciences), followed by immunoblotting with rabbit monoclonal anti-phospo ERK (1:1000 dilution), p38 (1:1000 dilution) or JNK (1:1000 dilution) antibody. The blots were incubated overnight at $4{ }^{\circ} \mathrm{C}$ with gentle shaking. Total MAPKs were detected with polyclonal antibodies for the various MAPKs as a control for sample loading. Nur77 protein expression in LBT2 was analyzed by incubation with an anti-Nur77 antibody (1:500 dilution; Santa Cruz Biotechnology, Inc., Santa Cruz, CA). Each blot was stripped and probed with $\beta$-actin antibody (1:5000 dilutions; Sigma) to confirm equal loading for each sample was used as a loading control.

\section{Results and Discussion}

GnRH induces expression of Nur77. Recently, members of the Nur77 family have been shown to play a role in the regulation of a number of cellular functions $(4,15,46-48)$. In the brain, Nur77 has been linked to the development and maturation of a specific set of central nervous system neurons and a possible association between the deregulation of Nur77 and neuron degeneration in Parkinson's disease has been reported $(49,50)$. The expression of Nur77 in the pituitary (35) suggests that it may play a role in the regulation of pituitary hormones and genes. However, physiological responses that regulate the expression of Nur77 in pituitary cells including gonadotropes have not been elucidated. In previous studies, we utilized DNA microarray analysis of the effects of GnRHA on LBT2 cells to gain insights into the potential mechanisms by which GnRHA affects mouse pituitary gonadotrope cells and found significant induction of Nur77 (36). Therefore, in the present studies, we first examined the induction of Nur77 in LBT2 cells by semi-quantitative RT/PCR analysis. Consistent with our previous study, using the Nur77 specific primers, PCR generated a $400 \mathrm{bp}$ product that corresponded to the published sequence (Fig. 1A). The increase in expression of Nur77 mRNA was rapid, reaching a maximum level (17-fold) within $2 \mathrm{~h}$ and then returning to nearly basal levels after $24 \mathrm{~h}$ of treatment. This finding of rapid induction of Nur77 is consistent with reports of its rapid induction in other systems $(3,4,37,38)$. Pretreatment of cells with a GnRH antagonist, Antide $(1 \mathrm{mM})$ completely blocked the effect of GnRHA (Fig. 1B), suggesting that the stimulatory effect of GnRHA is specific and achieved through its high affinity receptors present on cell membranes of LBT2 cells (36). The specificity of the effects is further supported by its dose-dependence, with an $\mathrm{IC}_{50}$ value of $\sim 0.05 \mathrm{nM}$ (Fig. 2). Pretreatment of the cells with the transcriptional inhibitor, actinomycin D, blocked the effects of GnRHA on induction of Nur77 mRNA (data not shown). Thus, the changes in the expression of Nur77 mRNA on GnRHA treatment can be attributed to an increase in mRNA biosynthesis, rather than to an alteration in mRNA stability and suggest that the increase in Nur77 mRNA levels induced by GnRHA is due to activation of transcription of the Nur77 gene.
A
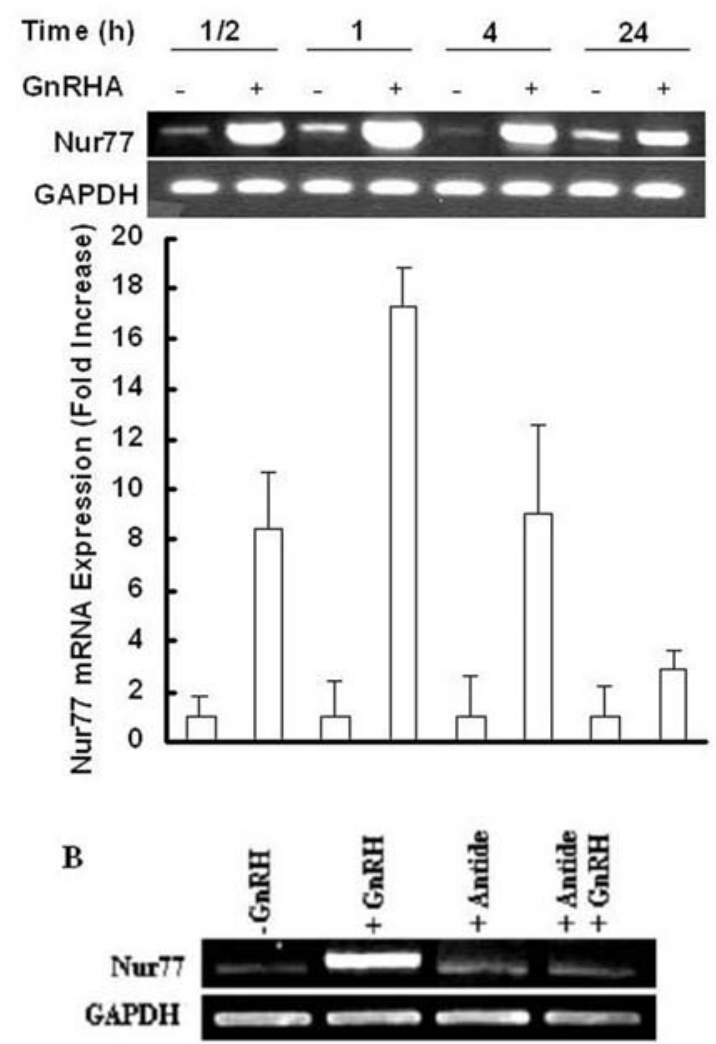

Figure 1. GnRHA induces expression of Nur77 in the mouse pituitary gonadotroph cell line, LBT2. Cells were serum-starved overnight and then treated with $10 \mathrm{nM}$ GnRHA for 1/2, 1, 2, 4 and $24 \mathrm{~h}$ (A). To block GnRH receptors, cells were pretreated with $1 \mu \mathrm{M}$ Antide for $1 \mathrm{~h}$ and then with $10 \mathrm{nM}$ GnRHA for $1 \mathrm{~h}(\mathrm{~B})$. Total RNA $(1 \mu \mathrm{g})$ was reverse transcribed. Nur77 cDNA was amplified using PCR with specific primers. The expression of GAPDH was used as an internal control. Nur77 mRNA expression was quantified and normalized using the values for the levels of GAPDH mRNA, which was used as an internal control for each sample. The data are representative of three independent experiments with bar graphs displaying the mean \pm SEM.

Next, we confirmed the induction of Nur77 at the protein level using Western blot analysis. LßT2 cells treated with vehicle expressed very low levels of an immunoreactive protein with a molecular weight of $\sim 77 \mathrm{kDa}$. The addition of GnRHA resulted in enhanced expression of Nur77 protein expression, with the levels increasing over time until $12 \mathrm{~h}$ (Fig. 3). Taken together our results demonstrate that GnRHA induces Nur77 expression through an effect on transcription and generates a Nur77 protein that corresponds to native Nur77.

In limited studies, regulation of expression of Nur77 by LH in testicular Leydig cells (10) and by LH and hCG in granulose cells of preovulatory follicles $(51,52)$ have been demonstrated, suggesting an important role of Nur77 in the LH-mediated steroidogenesis in Leydig cells and LH-mediated ovulatory process respectively. Similarly, regulation of expression of Nur77 by a variety of stress stimuli in CRHproducing neurons of the hypothalamus $(53,54)$ and by ACTH in adrenal gland leading to enhancement of steroid-21- $\alpha$ hydroxylase gene transcription $(18,55)$ has been shown. Our finding of induction of Nur77 expression by GnRH in the pituitary gonadotropes, together with its induction by $\mathrm{LH}$ in 


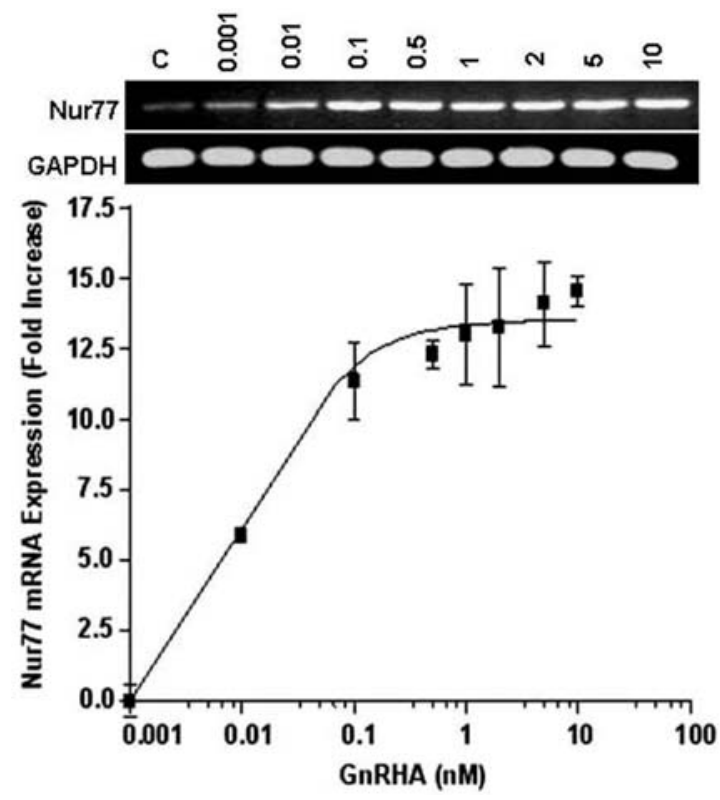

Figure 2. GnRHA induces Nur77 expression in LBT2 cells in a dosedependent manner. LBT2 cells were serum-starved overnight and then treated with different concentrations of GnRHA for $1 \mathrm{~h}$. Total RNA $(1 \mu \mathrm{g})$ was reverse transcribed. Nur77 cDNA was amplified using PCR with specific primers. The expression of Nur77 mRNA was normalized using the GAPDH internal control. The data are representative of three independent experiments and are shown as mean \pm SEM.

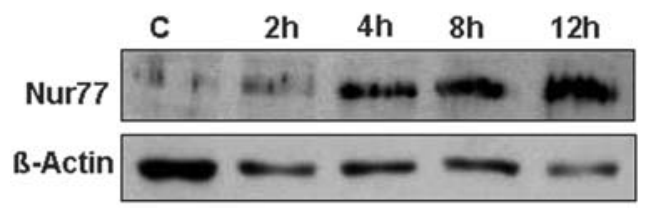

Figure 3. GnRHA induces expression of Nur77 protein in LBT2 cells. LßT2 cells were serum-starved overnight and then treated with $10 \mathrm{nM}$ GnRHA for the indicated time periods. The cells were washed with cold PBS and lysed in lysis buffer. Cell extract ( $40 \mu \mathrm{g}$ ) from each sample was analyzed by immunoblotting with Nur77 antibody. ß-actin was used as a loading control. The data are representative of two independent experiments.

the testicular Leydig cells and preovulatory follicles, suggest that Nur77 may play a dynamic role in the function of the hypothalamic-pituitary-gonadal axis. The physiological consequences of the GnRH effect on Nur77 expression in pituitary gonadotropes have yet to be determined, however.

Similarly, the effects of Nur77 on the downstream signaling pathways of pituitary gonadotropes have yet to be established. The role of Nur77 as a transcription factor is well documented $(56,57)$. Newly synthesized Nur77 protein translocates to nucleus where it binds to NGFI-B (Nur77) binding response elements (NBREs) as a monomer, homodimer, or heterodimer and activates the transcription of various downstream target genes (58). In this respect, Sadie et al (59) showed the existence of two nuclear receptor half-sites (NRS) at -244/-236 and $-15 /-7$ (relative to the translation start site) in the flanking sequence of the mouse GnRH receptor gene. Both these sites were shown to be overlapping binding sites for Nur77 and SF-1 transcription factor in vitro. Expression of Nur77 in the pituitary gonadotrope cell line ( $\alpha \mathrm{T} 31)$ has no effect on basal

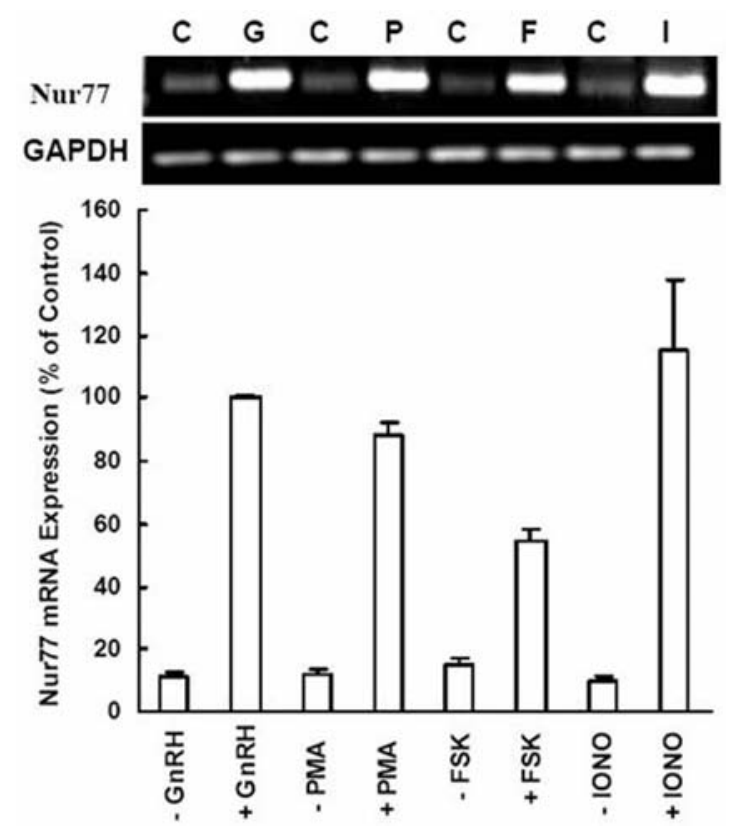

Figure 4. Multiple signaling pathways regulate induction of Nur77 expression by GnRHA. LBT2 cells were serum-starved overnight and then treated with $10 \mathrm{nM}$ GnRHA (G), $1 \mu \mathrm{M}$ PMA (P), $10 \mu \mathrm{M}$ forskolin (FSK) (F) or $1 \mathrm{M}$ ionomycin (IONO) (I) for $1 \mathrm{~h}$. Total RNA (1 $\mu \mathrm{g})$ was reverse transcribed and analyzed using PCR with Nur77 cDNA-specific primers as described above. The expression of GAPDH was used as an internal control. The Nur77 mRNA expression was quantified and normalized using the GAPDH internal controls. The normalized values were then compared with the normalized values for the expression of Nur77 induced by GnRHA, which was arbitrarily assigned a value of $100 \%$. The data are representative of three independent experiments and are shown as the mean \pm SEM.

promoter activity of GnRH receptor, but suppresses the PKA-induced promoter activity in the absence of SF-1 binding site at $-15 /-7$ NRS, suggesting that Nur77 may serve as a negative regulator of PKA-induced $\mathrm{G} n \mathrm{RH}$ receptor gene expression (59).

Multiple signaling pathways are involved in GnRH-mediated induction of Nur77 gene expression in L $\beta T 2$ cells. GnRH is a hypothalamic decapeptide, which serves as a key regulator of the reproductive system. GnRH signals are transmitted through a specific G-protein coupled receptor, the $\mathrm{GnRH}$ receptor, which on activation interacts with the heterotrimeric $\mathrm{G}_{\mathrm{q}}$ protein $(60,61)$. This interaction results in recruitment of a diverse group of intracellular signaling cascades, including protein kinase A (PKA), protein kinase C (PKC), G-protein coupled receptor kinases, calcium-calmodulin $\left(\mathrm{Ca}^{2+} / \mathrm{CaM}\right)$, MAPK kinase pathways and increases intracellular calcium levels in pituitary and other cells that express GnRH receptors (reviewed in ref. 43). These signaling cascades culminate mainly in the production and secretion of the LH and FSH.

To determine which GnRHR-coupled signaling pathway mediates the GnRH-induced upregulation of expression of Nur77, we treated LBT2 cells with signaling agonists. Both $10 \mu \mathrm{M}$ forskolin (FSK) and $1 \mu \mathrm{M}$ PMA, which activate PKA and $\mathrm{PKC}$ pathways respectively, significantly increased the expression of Nur77 mRNA (Fig. 4). Similarly, $1 \mu \mathrm{M}$ ionomycin, a calcium ionophore increased the expression of Nur77 (Fig. 4). As these results indicated that both the PKA 

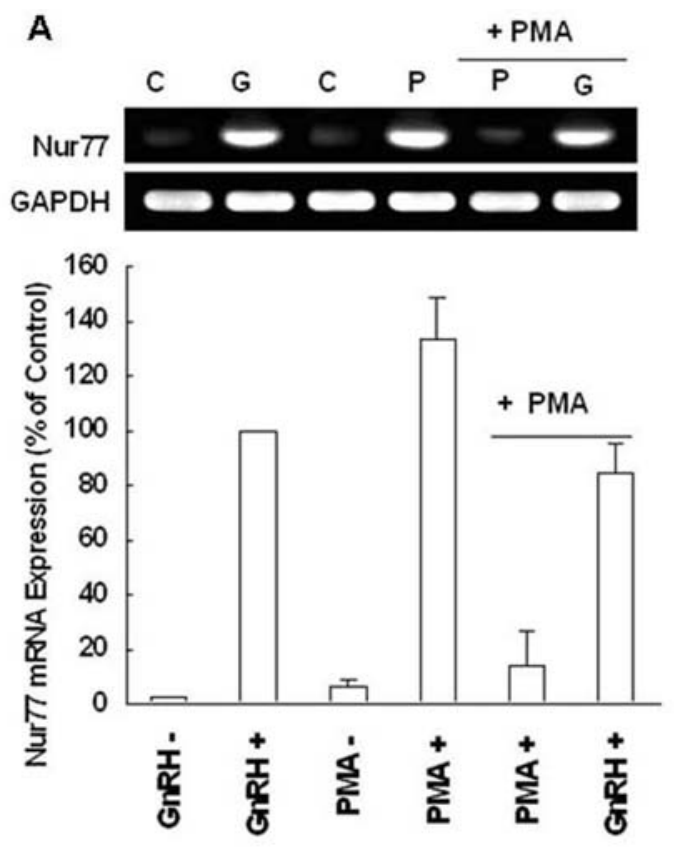
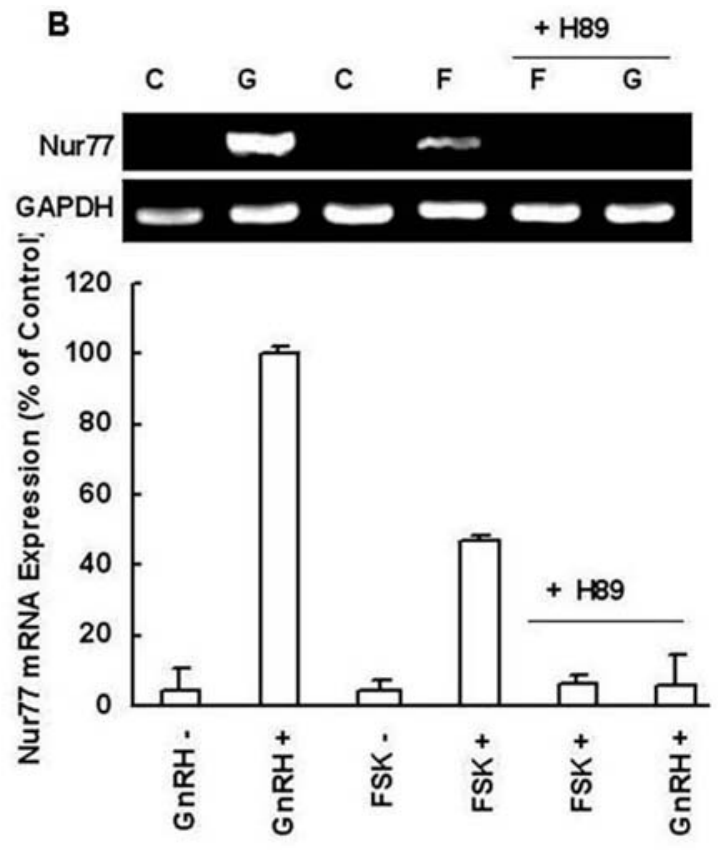

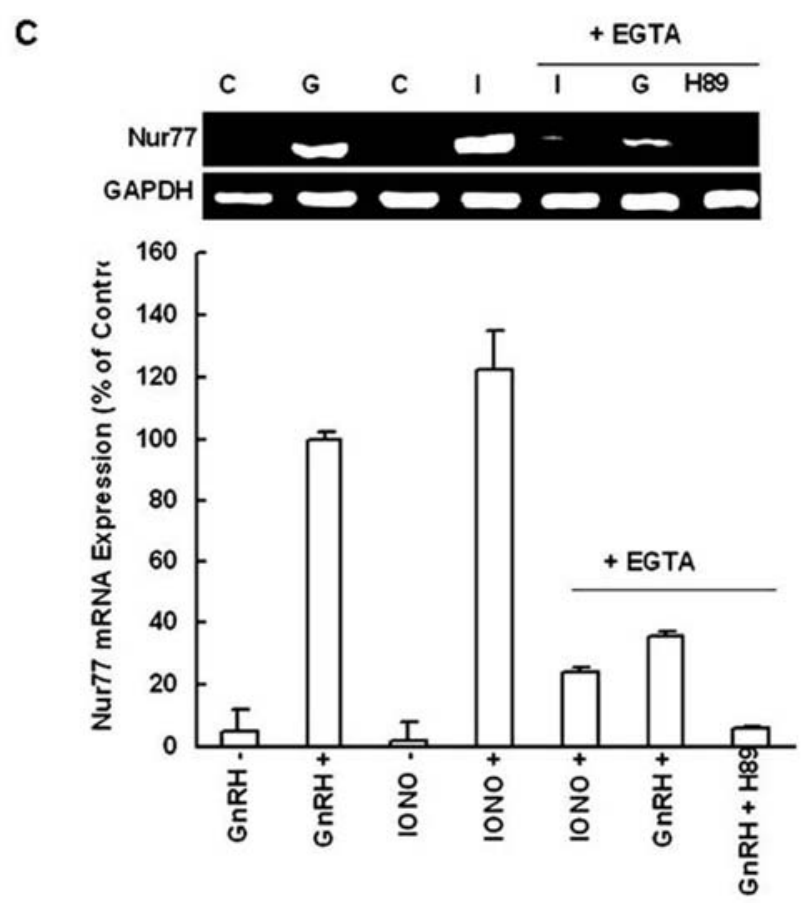

Figure 5. Blockade of the PKA pathway and calcium influx, but not the PKC pathway, inhibits GnRHA-induced Nur77 mRNA expression in LßT2 cells. To deplete PKC, the cells were incubated overnight with $10 \mu \mathrm{M}$ PMA and then treated with $1 \mu \mathrm{M}$ PMA (P) or $10 \mathrm{nM}$ GnRHA (G) for $1 \mathrm{~h}(\mathrm{~A})$. To inhibit the PKA pathway, the cells were pretreated with $30 \mathrm{M} \mathrm{H} 89$ for $1 \mathrm{~h}$ and then treated with $10 \mu \mathrm{M}$ FSK (F) or $10 \mathrm{nM}$ GnRHA (G) for $1 \mathrm{~h}$ (B). To deplete extracellular calcium, the cells were pretreated with $2.5 \mathrm{mM}$ EGTA for $20 \mathrm{~min}$ and then treated with $1 \mathrm{M}$ ionomycin (I) or $10 \mathrm{nM}$ GnRHA (G). To deplete extracellular calcium and to block PKA pathway, cells were treated with $2.5 \mathrm{mM}$ EGTA and $30 \mu \mathrm{M}$ H89 for $1 \mathrm{~h}$. Total RNA (1 $\mu \mathrm{g}$ ) from each sample was reverse transcribed and analyzed for Nur77 mRNA expression using PCR. The expression was normalized using the GAPDH internal control. The normalized values were then compared with the normalized expression of Nur77 on GnRHA induction, which was arbitrarily assigned a value of $100 \%$. Bars shown represent pretreatment. The data are representative of three independent experiments and are shown as the mean \pm SEM.

and PKC signaling pathways are involved in the GnRHmediated induction of Nur77, we tested selective inhibitors of the PKA and PKC pathways for their ability to block induction of Nur77. Pretreatment of cells with $30 \mu \mathrm{M} \mathrm{H}-89$ (PKA inhibitor) significantly inhibited GnRHA- and FSKinduced expression of Nur77 (Fig 5B). Pretreatment of cells overnight with $1 \mu \mathrm{M}$ PMA, which depletes PKC, resulted in a complete loss of stimulatory effect of PMA but marginally inhibited the GnRHA-induced expression of Nur77 (Fig. 5A). The addition of $2.5 \mathrm{mM}$ EGTA to the extracellular medium, which chelates calcium, significantly reduced the effects of $1 \mu \mathrm{M}$ ionomycin and GnRHA on Nur77 mRNA expression (Fig. 5C). Taken together, these results suggest that the effects of GnRHA on the induction of Nur77 are mediated through multiple signaling pathways. These observations concur with the demonstration of the involvement of multiple 


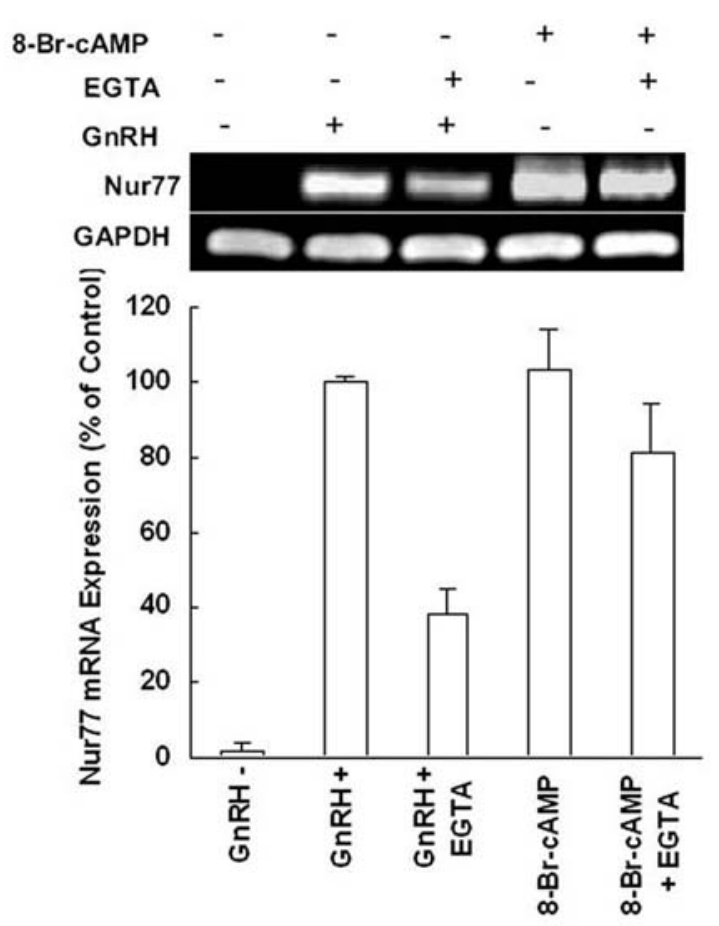

Figure 6. GnRHA induces Nur77 mRNA expression through the activation of the cAMP-PKA signaling pathway and calcium influx. LBT2 cells were serum-starved overnight and then pretreated with $2.5 \mathrm{mM}$ EGTA $20 \mathrm{~min}$ followed by treatment with $10 \mathrm{nM}$ GnRHA or $1 \mathrm{mM}$ 8-Br-cAMP for $1 \mathrm{~h}$. Total RNA $(1 \mu \mathrm{g})$ was reverse transcribed and analyzed for Nur77 mRNA expression using PCR. The expression was quantified and normalized using the GAPDH internal controls. The normalized values were then compared with the normalized expression of Nur77 on GnRHA induction, which was arbitrarily assigned a value of $100 \%$. The data are representative of three independent experiments and are shown as the mean \pm SEM.

pathways and specifically these pathways in the regulation by $\mathrm{GnRH}$ of various GnRH-response genes including LHß, FSHß, Egr1 and Egr2 in pituitary cells (62).

Blockade of PKA and calcium influx, but not PKC inhibits GnRH-induced activation of Nur77 mRNA expression in LjT2 cells. As reported above it appears that GnRHA activation of most, if not all, the major signaling pathways is involved in its ability to regulate the expression of Nur77 gene in LßT2 cells. To further identify the major pathway, we tested PKA- and PKC-specific inhibitors and extracellular calcium chelator for their ability to block Nur77 mRNA induction by GnRHA. As reported above, treatment of LBT2 cells with $10 \mu \mathrm{M}$ PMA overnight resulted in a significant $(90 \%)$ inhibition of PMAinduced Nur77 expression, but showed only a marginal inhibition of GnRHA-induced expression (Fig. 5A), indicating that PKC activation can induce Nur77 mRNA expression, but the ability of GnRHA to upregulate Nur77 does not seem to rely on PKC activation. In contrast, pretreatment of LBT2 cells with the PKA-specific inhibitor, H-89 $(30 \mu \mathrm{M})$, significantly inhibited both GnRHA-induced and FSK-induced Nur77 mRNA expression ( 90\%) (Fig. 5B). Treatment of LBT2 cells with $1 \mathrm{mM} 8$-Br-cAMP, a cell membrane permeable analog of cAMP, was found to significantly increase the expression of Nur77 mRNA (Fig. 6). These results suggest that GnRH induces expression of Nur77 mRNA expression primarily through cAMP/PKA cascade. To rule out the possibility that

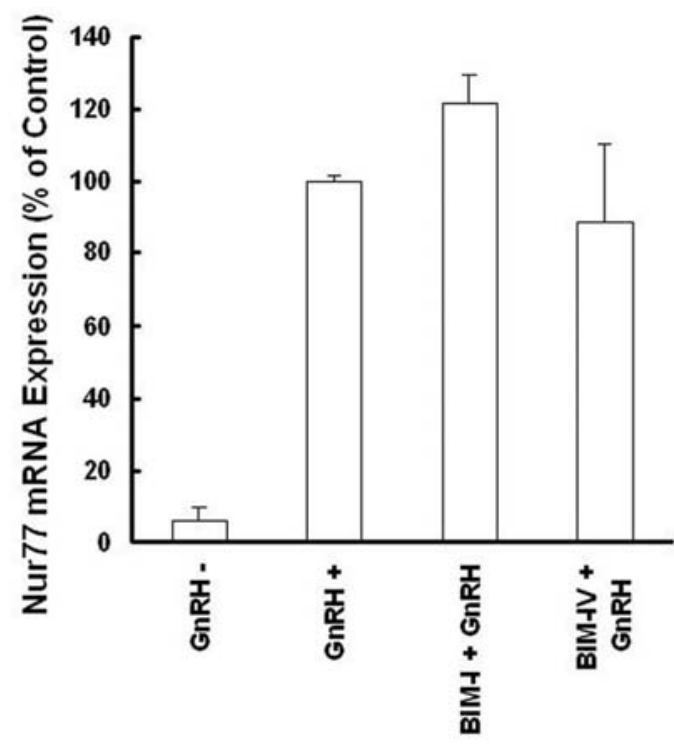

Figure 7. Activation of PKC is not involved in regulation of induction of Nur77 mRNA by GnRHA in LBT2 cells. Cells were serum-starved overnight and then pretreated with PKC-specific inhibitors [BIM-I $(1 \mu \mathrm{M})$ or BIM-IV $(5 \mu \mathrm{M})$ ] for $1 \mathrm{~h}$ followed by treatment with $10 \mathrm{nM}$ GnRHA for $1 \mathrm{~h}$. Total RNA $(1 \mu \mathrm{g})$ was reverse transcribed and Nur77 mRNA expression was analyzed using PCR with specific primers. Nur77 mRNA expression was quantified and normalized using the GAPDH internal control. The normalized values were then compared with the normalized expression of Nur77 on GnRHA induction, which was arbitrarily assigned a value of $100 \%$. The data are representative of three independent experiments and are shown as the mean \pm SEM.

PKC signaling pathways play a major role in the induction of Nur77 expression in LBT2 cells by GnRH, we analyzed the role of $\mathrm{PKC}$ in more detail using $\mathrm{PKC}$-specific inhibitors BIM-I and BIM-IV. As shown in Fig. 7, pretreatment of LßT2 cells with BIM-I $(1 \mu \mathrm{M})$ or BIM-IV $(5 \mu \mathrm{M})$ for $1 \mathrm{~h}$ prior to the treatment of cells with GnRHA for $1 \mathrm{~h}$ did not affect GnRHA-induced Nur77 mRNA expression further indicating that the PKC signaling cascade may not be involved in the induction of Nur77 mRNA by GnRHA in LßT2 cells. Our findings are consistent with the reports of the involvement of activation of cAMP/PKA pathway in the induction of Nur77 transcription by other hormones in other tissues, including corticotropin (ACTH) treatment of adenocortical Y1 cells (18), LH treatment of testicular Leydig cells (10), parathyroid treatment of osteoblastic cells (63) and thyroid stimulating hormone treatment of thyroid cells (64). However, this cAMPdependence does not seem to be a general phenomenon as the PKC cascade has been reported to be a major pathway involved in Nur77 expression in C2C12 myoblastic cells (65), LS-180 colon adenocarcinoma cells (66) and T cells (67).

To determine the contribution of extracellular calcium to GnRH-induced expression of Nur77 mRNA, we investigated the effect of extracellular calcium chelation on Nur77 mRNA expression. Treatment of LßT2 cells with EGTA (2.5 mM for $20 \mathrm{~min}$ ) prior to treatment with either $1 \mu \mathrm{M}$ ionomycin or $10 \mathrm{nM}$ GnRH significantly blocked the effect of both ionomycin (80\%) and GnRHA (65\%) on Nur77 mRNA expression (Fig. 5C). Pretreatment of LBT2 cells with H-89 $(30 \mu \mathrm{M})$ plus EGTA $(2.5 \mathrm{mM})$ for $1 \mathrm{~h}$ completely blocked the GnRHA-induced expression of Nur77 mRNA (Fig. 5C). 
A

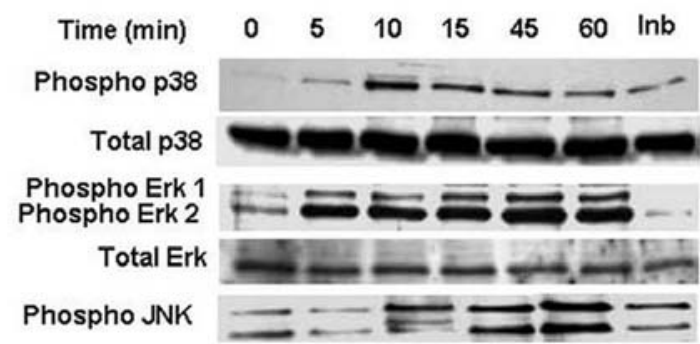

B
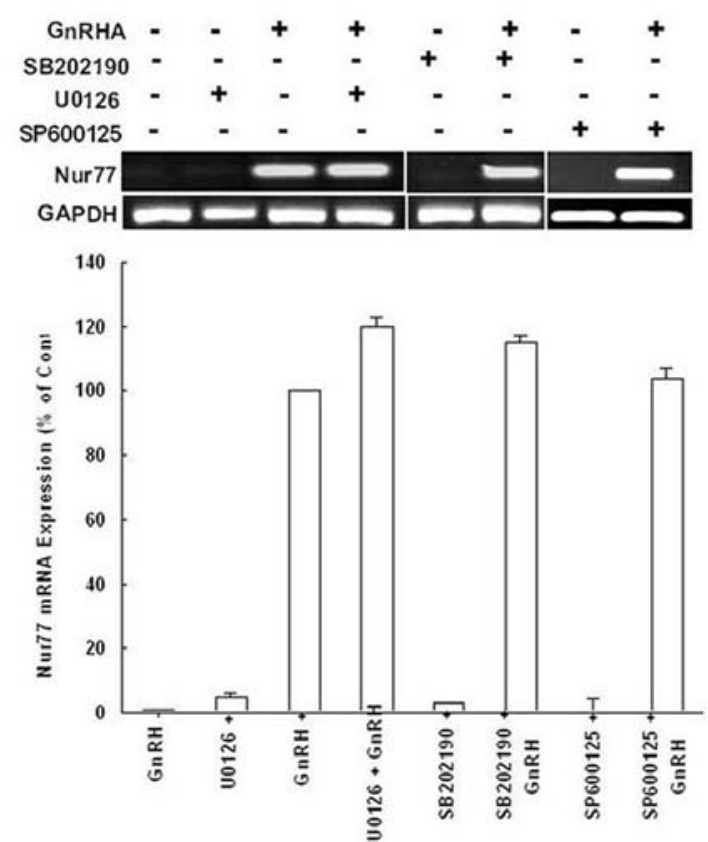

Figure 8. Activation of MAPK signaling pathways are not involved in induction of Nur77 mRNA by GnRHA in LßT2 cells. Cells were serumstarved overnight and then treated with $10 \mathrm{nM}$ GnRHA for the indicated time periods (A). After treatment, the cells were washed with cold PBS and lysed in lysis buffer. Cell lysate $(40 \mu \mathrm{g})$ from each sample was analyzed on Western blot using the phospho antibodies specific for p38, Erk1/2 or JNK. The intensity of staining of the antibodies reactive with $\mathrm{p} 38$ total protein or Erk1/2 total protein was used to confirm equal loading for each sample (A). To inhibit the phosphorylation of $\mathrm{p} 38$, Erk $1 / 2$ or JNK and to determine Nur77 expression, cells were pretreated with specific inhibitor for p38 (SB202190, $2 \mu \mathrm{M}$ ), Erk1/2 (U0126, $10 \mu \mathrm{M}$ ) or JNK (SP600125, $20 \mu \mathrm{M}$ ) for 30 min followed by treatment with $10 \mathrm{nM} \mathrm{GnRHA}$ for 5 min for p38 and for 45 min for both Erk1/2 and JNK. Total RNA (1 $\mu \mathrm{g})$ was reverse transcribed and analyzed for Nur77 mRNA expression using PCR. GAPDH mRNA expression was used as an internal control. Nur77 mRNA expression was quantified and normalized using the GAPDH internal controls (B). The normalized values were then compared with the normalized expression of Nur77 on GnRHA induction, which was arbitrarily assigned a value of $100 \%$. The data are representative of three independent experiments and are shown as the mean \pm SEM.

Pretreatment of cells with EGTA partially (20\%) blocked the stimulatory effect of 8-Br-cAMP (Fig. 6), suggesting the importance of calcium influx in activation of Nur77 expression by GnRHA. Calcium has been demonstrated to have multiple modulatory influences on hormone-stimulated adenylate cyclase $(68,69)$ and to play an important in role in pulsatile release of gonadotropin-releasing hormone (70) and in stimulating the effect of $\mathrm{GnRH}$ on secretion and expression of $\mathrm{LH}$ in gonadotropes $(71,72)$. Since, 8 -Br-cAMP directly activates PKA without involving adenylate cyclase, therefore, our results strongly suggest that induction of Nur77 by GnRH is mediated by two independent pathways namely calcium influx and the PKA pathway, but acts predominately through activation of PKA signaling. It remains to be determined if PKA itself or other downstream kinase target Nur77.

Blockade of phosphorylation of p38, Erk1/2 and JNK does not block GnRHA-induced Nur77 expression. PKC activation has been shown to be a major signaling pathway by which GnRH in pituitary and other cells mediates its effects $(73,74)$. As our studies indicate that cAMP/PKA acts as the primary signaling pathway in induction of Nur77 expression by GnRHA in LßT2 cells, we extended our study to the evaluation of molecules that act downstream of PKC, including the analysis of the activation states of Erk1/2, p38 and JNK.

In agreement with earlier published studies (75), treatment of LBT2 cells with GnRHA for various time periods resulted in a time-dependent phosphorylation of p38, Erk1/2 and JNK (Fig. 8). Phosphorylation of p38 occurred within 5 min of treatment, reaching a maximum level within $10 \mathrm{~min}$ (Fig. 8A). The maximum levels of phosphorylation of Erk1/2 and JNK were attained within 45 and 60 min of treatment, respectively (Fig. 8A). As expected, pretreatment of cells with p38 MAPK inhibitor SB202190 (2 $\mu \mathrm{M}$ for $30 \mathrm{~min})$, MEK-specific inhibitor U0126 (10 $\mu \mathrm{M}$ for $30 \mathrm{~min})$ or JNK inhibitor SP600125 (20 $\mu \mathrm{M}$ for $45 \mathrm{~min})$ resulted in inhibition of phosphorylation of p38, Erk1/2 and JNK (Fig. 8A). Notably, however, these pretreatments failed to block the GnRHAinduced expression of Nur77 (Fig. 8B). These results strongly suggest that even though GnRH activates PKC signaling in LBT2 cells, this pathway is not involved in the GnRH-mediated induction of Nur77 expression.

Currently, the physiological significance of the induction of Nur77 by GnRHA in pituitary gonadotropes remains unclear. Using DNA microarray analysis technique, we (36) and others (76) have shown changes in expression of a large number of genes in LßT2 cells on treatment with GnRH or GnRHA for 1, 2, 4 and $24 \mathrm{~h}$. Since Nur77 is an early response gene and is known to regulate the expression of other genes, it is plausible that Nur77 serves as a signal that mediates the ability of $\mathrm{GnRH}$ to regulate the secretion and expression of pituitary gonadotropins (reviewed in ref. 77). It is possible that some of these functions of $\mathrm{GnRH}$, including secretion and expression of gonadotropins, may be mediated through Nur77. It should be noted, however, that knockout mice have a normal phenotype (19). This may reflect a functional redundancy among Nur77 family members such that stimuli that induce Nur77 can also induce expression of the other family members, such as Nurr1 (10). It is also possible that Nur77 is not involved in the regulation of the secretion and expression of gonadotropins in pituitary, but regulates the extra-pituitary functions of $\mathrm{GnRH}$ such as regulation of tumor cell proliferation and apoptosis.

GnRH and its high affinity receptors have been identified in a variety of extra-pituitary tissues including ovary, testis, breast and prostrate (78-82) and various tumors (83-90). Several studies suggest that the GnRH is involved in tumor cell proliferation, apoptosis, cell cycle arrest $(41,91-94)$ and cytoskeletal rearrangements (42). Nur77 has been reported to regulate cell proliferation of prostate, colon, pancreatic and 
gastric cancers $(9,11,14,15,26)$. Thus we anticipate that Nur77 may be involved mechanistically in at least some of the functions mediated by GnRH and its high affinity receptors. The molecular mechanism(s) by which Nur77 exerts GnRH function in pituitary and extra-pituitary tissues and antitumor effect of GnRH is an area of active investigation.

In summary, we have shown that GnRH regulates the expression of the orphan nuclear receptor gene, Nur77, in the mouse pituitary gonadotrope cell line, LßT2. GnRHA treatment induces Nur77 gene expression through diverse signaling pathway. However, cAMP-PKA signaling pathway appears to be the major signaling pathway involved in GnRH-induced Nur77 expression. Identification of signaling mechanism(s) regulated by Nur77 will be necessary for a full understanding of the role of Nur77 in the GnRH-mediated responses in pituitary, extra-pituitary tissues and tumors.

\section{Acknowledgements}

This study was supported by a grant from NCI CA60871 (SSK) and financial support from the James Graham Brown Cancer Center, University of Louisville (SSK).

\section{References}

1. Law SW, Conneely OM, DeMayo FJ and O'Malley BW: Identification of a new brain-specific transcription factor, NURR1. Mol Endocrinol 6: 2129-2135, 1992.

2. Ohkura N, Hijikuro M, Yamamoto A and Miki K: Molecular cloning of a novel thyroid/steroid receptor superfamily gene from cultured rat neuronal cells. Biochem Biophys Res Commun 205: 1959-1965, 1994.

3. Milbrandt J: Nerve growth factor induces a gene homologous to the glucocorticoid receptor gene. Neuron 1: 183-188, 1988.

4. Hazel TG, Nathans D and Lau LF: A gene inducible by serum growth factors encodes a member of the steroid and thyroid hormone receptor superfamily. Proc Natl Acad Sci USA 85: 8444-8448, 1988.

5. Fahrner TJ, Carroll SL and Milbrandt J: The NGF-1B protein, and inducible member of the thyroid/steroid receptor family, is rapidly modified posttranslationally. Mol Cell Biol 10: 6454-6459, 1990.

6. Pei L, Castrillo A, Chen M, Hoffmann A and Tontonoz P: Induction of NR4A orphan receptor expression in macrophages in response to inflammatory stimuli. J biol Chem 280 : 29256-29262, 2005.

7. Kovalovsky D, Paez Pereda M, Labeur M, Renner U, Holsboer F, Stalla GK and Arzt E: Nur77 induction and activation are necessary for interleukin-1 stimulation of proopiomelanocortin in AtT-20 corticotrophs. FEBS Lett 563: 229-233, 2004.

8. Jimenez-Cervantes C, Pichon B, Dumont JE and Maenhaut C: Activation by thyroid stimulating hormone of nerve growth factor-induced gene-B expression in thyrocytes in culture: relation with proliferation and specific gene expression. Biochim Biophys Acta 1403: 232-244, 1988.

9. Wilson AJ, Arango D, Mariadason JM, Heerdt BG and Augenlicht LH: TR3/Nur77 in colon cancer cell apoptosis. Cancer Res 63: 5401-5407, 2003.

10. Song KH, Park JI, Lee MO, Soh J, Lee K and Choi HS: LH induces orphan nuclear receptor Nur77 gene expression in testicular Leydig cells. Endocrinology 142: 5116-5123, 2001.

11. Chintharlapalli S, Burghardt R, Papineni S, Ramaiah S, Yoon K and Safe S: Activation of Nur77 by selected 1,1-Bis(3'-indolyl)1 -(p-substituted phenyl)methanes induces apoptosis through nuclear pathways. J Biol Chem 280: 24903-24914, 2005.

12. Song KH, Park, YY, Park KC, Hong CY, Park JH, Shong M, Lee K and Choi HS: The atypical orphan nuclear receptor DAX-1 interacts with orphan nuclear receptor Nur77 and represses its transactivation. Mol Endocrinol 18: 1929-1940, 2004.

13. Predki PF, Zamble D, Sarkar B and Giguere V: Ordered binding of retinoic acid and retinoid- $\mathrm{X}$ receptors to asymmetric response elements involves determinants adjacent to the DNA-binding domain. Mol Endocrinol 8: 31-39, 1994.
14. Kang HJ, Song MR, Lee SK, Shin EC, Choi YH, Kim SJ, Lee JW and Lee MO: Retinoic acid and its receptors repress the expression and transactivation functions of Nur77: a possible mechanism for the inhibition of apoptosis by retinoic acid. Exp Cell Res 256: 545-554, 2000.

15. Wu WS, Xu ZX, Ran R, Meng F and Chang KS: Promyelocytic leukemia protein PML inhibits Nur77-mediated transcription through specific functional interactions. Oncogene 21: 3925-3933, 2002.

16. Maira M, Martens C, Batsche E, Gauthier Y and Drouin J: Dimer-specific potentiation of NGFI-B (Nur77) transcriptional activity by the protein kinase A pathway and AF-1-dependent coactivator recruitment. Mol Cell Biol 23: 763-776, 2003.

17. Sohn YC, Kwak E, Na Y, Lee JW and Lee SK: Silencing mediator of retinoid and thyroid hormone receptors and activating signal cointegrator-2 as transcriptional coregulators of the orphan nuclear receptor Nur77. J Biol Chem 276: 43734-43739, 2001.

18. Wilson TE, Mouw AR, Weaver CA, Milbrandt J and Parker KL: The orphan nuclear receptor NGFI-B regulates expression of the gene encoding steroid 21-hydroxylase. Mol Cell Biol 13: 861-868, 1993.

19. Crawford PA, Sadovsky Y, Woodson K, Lee SL and Milbrandt J: Adrenocortical function and regulation of the steroid 21hydroxylase gene in NGFI-B-deficient mice. Mol Cell Biol 15: 4331-4336, 1995

20. Fernandez PM, Brunel F, Jimenez MA, Saez, JM, Cereghini S and Zakin MM: Nuclear receptors Nor1 and NGFI-B/Nur77 play similar, albeit distinct, roles in the hypothalamo-pituitaryadrenal axis. Endocrinology 141: 2392-2400, 2000.

21. Stocco CO, Zhong L, Sugimoto Y, Ichikawa A, Lau LF and Gibori G: Prostaglandin F2alpha-induced expression of 20alphahydroxysteroid dehydrogenase involves the transcription factor NUR77. J Biol Chem 275: 37202-37211, 2000.

22. Liu ZG, Smith SW, McLaughlin KA, Schwartz LM and Osborne BA: Apoptotic signals delivered through the T-cell receptor of a T-cell hybrid require the immediate-early gene nur77. Nature 367: 281-284, 1994.

23. Cheng LE, Chan FK, Cado D and Winoto A: Functional redundancy of the Nur77 and Nor-1 orphan steroid receptors in T-cell apoptosis. EMBO J 16: 1865-1875, 1997.

24. Li Y, Lin B, Agadir A, Liu R, Dawson MI, Reed JC, Fontana JA, Bost F, Hobbs PD, Zheng Y, Chen GQ, Shroot B, Mercola D and Zhang XK: Molecular determinants of AHPN (CD437)induced growth arrest and apoptosis in human lung cancer cell lines. Mol Cell Biol 18: 4719-47131, 1998.

25. Uemura $H$ and Chang C: Antisense TR3 orphan receptor can increase prostate cancer cell viability with etoposide treatment. Endocrinology 139: 2329-2334, 1998.

26. Woronicz JD, Calnan B, Ngo V and Winoto A: Requirement for the orphan steroid receptor Nur77 in apoptosis of T-cell hybridomas. Nature 367: 277-281, 1994.

27. He YW: Orphan nuclear receptors in T lymphocyte development. J Leukoc Biol 72: 440-446, 2002.

28. Calnan BJ, Szychowski S, Chan FK, Cado D and Winoto A: A role for the orphan steroid receptor Nur77 in apoptosis accompanying antigen-induced negative selection. Immunity 3 : 273-282, 1995 .

29. Hazel TG, Misra R, Davis IJ, Greenberg ME and Lau LF: Nur77 is differentially modified in PC 12 cells upon membrane depolarization and growth factor treatment. Mol Cell Biol 11: 3239-3246, 1991

30. Suzuki S, Suzuki N, Mirtsos C, Horacek T, Lye E, Noh SK, Ho A, Bouchard D, Mak, TW and Yeh WC: Nur77 as a survival factor in tumor necrosis factor signaling. Proc Natl Acad Sci USA 100: 8276-8280, 2003.

31. Lin B, Kolluri SK, Lin F, Liu W, Han YH, Cao X, Dawson MI, Reed JC and Zhang XK: Conversion of Bcl-2 from protector to killer by interaction with nuclear orphan receptor Nur77/TR3. Cell 116: 527-540, 2004.

32. Yoo Yg, Yeo MG, Kim DK, Park H and Lee MO: Novel function of orphan nuclear receptor Nur77 in stabilizing hypoxia-inducible factor-1alpha. J Biol Chem 279: 53365-53373, 2004.

33. Ramaswamy S, Ross KN, Lander ES and Golub TR: A molecular signature of metastasis in primary solid tumors. Nat Genet 33: 49-54, 2003.

34. Ke N, Claassen G, Yu DH, Albers A, Fan W, Tan P, Grifman M, $\mathrm{Hu}$ X, Defife Nguy V, Meyhack B, Brachat A, Wong-Staal F and Li QX: Nuclear hormone receptor NR4A2 is involved in cell transformation and apoptosis. Cancer Res 64: 8208-8212, 2004. 
35. Bandoh S, Tsukada T, Maruyama K, Ohkura N and Yamaguchi K: Differential expression of NGFI-B and RNR-1 genes in various tissues and developing brain of the rat: comparative study by quantitative reverse transcription-polymerase chain reaction. $\mathbf{J}$ Neuroendocrinol 9: 3-8, 1997.

36. Kakar SS, Winters SJ, Zacharias W, Miller DM and Flynn S: Identification of distinct gene expression profiles associated with treatment of LbetaT2 cells with gonadotropin-releasing hormone agonist using microarray analysis. Gene 308: 67-77, 2003.

37. Nakai A, Kartha S, Sakurai A, Toback FG and DeGroot LJ: A human early response gene homologous to murine nur77 and rat NGFI-B, and related to the nuclear receptor superfamily. Mol Endocrinol 4: 1438-1443, 1990.

38. Ryseck RP, Macdonald-Bravo H, Mattei MG, Ruppert S and Bravo R: Structure, mapping and expression of a growth factor inducible gene encoding a putative nuclear hormonal binding receptor. EMBO J 8: 3327-3335, 1989.

39. Fink G: Gonadotropin secretion and its control. In: The Physiology of Reproduction. Knobil E, Neill JD (eds). Raven, New York, pp1349-1377, 1988.

40. Kalnay A, Palyi I, Vincze B, Mihalik R, Mezo I, Pato J, Seprodi J, Lovas S and Murphy RF: Influence on antiproliferative activity of structural modification and conjugation of gonadotropinreleasing hormone $(\mathrm{GnRH})$ analogues. Cell Prolif 33: 275-285, 2000.

41. Kraus S, Levy G, Hanoch T, Naor Z and Seger R: Gonadotropin-releasing hormone induces apoptosis of prostate cancer cells: role of c-Jun NH2-terminal kinase, protein kinase B, and extracellular signal-regulated kinase pathways. Cancer Res 64: 5736-5744, 2004

42. Davidson L, Pawson AJ, Millar RP and Maudsley S: Cytoskeletal reorganization dependence of signaling by the gonadotropin-releasing hormone receptor. J Biol Chem 279: 1980-1993, 2004

43. Kakar SS, Malik MT, Winters SJ and Mazhawidza W: Gonadotropin-releasing hormone receptors: structure, expression, and signaling transduction. Vitam Horm 69: 151-207, 2004.

44. Winters SJ, Ghooray D, Fuji Y, Moore JP Jr, Nevitt JR and Kakar SS: Transcriptional regulation of follistatin by GnRH in mouse gonadotroph cell lines: evidence for a role for cAMP signaling. Mol Cell Endocrinol 271: 45-54, 2007.

45. Hamid T and Kakar SS: PTTG/securin activates expression of p53 and modulates its function. Mol Cancer 8: 18, 2004.

46. De Silva S, Han S, Zhang X, Huston DP, Winoto A and Zheng B: Reduction of the incidence and severity of collagen-induced arthritis by constitutive Nur77 expression in the T cell lineage. Arthritis Rheum 52: 333-338, 2005.

47. Maxwell MA, Cleasby ME, Harding A, Stark A, Cooney GJ and Muscat GE: Nur77 regulates lipolysis in skeletal muscle cells: evidence for crosstalk between the beta-adrenergic and an orphan nuclear hormone receptor pathway. J Biol Chem 280: 12573-12584, 2005.

48. Kolluri SK, Bruey-Sedano N, Cao X, Lin B, Lin F, Han YH, Dawson MI and Zhang XK: Mitogenic effect of orphan receptor TR3 and its regulation by MEKK1 in lung cancer cells. Mol Cell Biol 23: 8651-8567, 2003

49. Saucedo-Cardenas O and Conneely OM: Comparative distribution of NURR1 and NUR77 nuclear receptors in the mouse central nervous system. J Mol Neurosci 7: 51-63, 1996.

50. Zetterstrom RH, Solomin L, Mitsiadis T, Olson L and Perlmann T: Retinoid X receptor heterodimerization and developmental expression distinguish the orphan nuclear receptors NGFI-B, Nurr1, and Nor1. Mol Endocrinol 10: 1656-1666, 1996.

51. Park JI, Park HJ, Choi HS, Lee K, Lee WK and Chun SY: Gonadotropin regulation of NGFI-B messenger ribonucleic acid expression during ovarian follicle development in the rat. Endocrinology 142: 3051-3059, 2001

52. Park JI, Park HJ, Lee YI, Seo YM and Chun SY: Regulation of NGFI-B expression during the ovulatory process. Mol Cell Endocrinol 202: 25-29, 2003.

53. Honkaniemi J and Sharp FR: Prolonged expression of zinc finger immediate-early gene mRNAs and decreased protein synthesis following kainic acid induced seizures. Eur J Neurosci 11: 10-17, 1999.

54. Murphy EP and Conneely OM: Neuroendocrine regulation of the hypothalamic pituitary adrenal axis by the nurr1/nur77 subfamily of nuclear receptors. Mol Endocrinol 11: 39-47, 1997.

55. Davis IJ and Lau LF: Endocrine and neurogenic regulation of the orphan nuclear receptors Nur77 and Nurr-1 in the adrenal glands. Mol Cell Biol 14: 3469-3483, 1994.
56. Bassett MH, Suzuki T, Sasano $\mathrm{H}$, De Vries CJ, Jimenez PT, Carr BR and Rainey WE: The orphan nuclear receptor NGFIB regulates transcription of 3beta-hydroxysteroid dehydrogenase. Implications for the control of adrenal functional zonation. J Biol Chem 279: 37622-37630, 2004.

57. Hsu HC, Zhou T and Mountz JD: Nur77 family of nuclea hormone receptors. Curr Drug Targets Inflamm Allergy 3: 413-423, 2004

58. Mynard V, Latchoumanin O, Guignat L, Devin-Leclerc J, Bertagna X, Barre BF, Agart J, Coqueret $\mathrm{O}$ and Catelli MG: Synergistic signaling by corticotropin-releasing hormone and leukemia inhibitory factor bridged by phosphorylated 3',5'-cyclic adenosine monophosphate response element binding protein at the Nur response element (NurRE)-signal transducers and activators of transcription (STAT) element of the proopiomelanocortin promoter. Mol Endocrinol 18: 2997-3010, 2004.

59. Sadie H, Styger G and Hapgood J: Expression of the mouse gonadotropin-releasing hormone receptor gene in alpha T3-1 gonadotrope cells is stimulated by cyclic $3^{\prime}, 5^{\prime}$-adenosine monophosphate and protein kinase A, and is modulated by Steroidogenic factor-1 and Nur77. Endocrinology 144: 1958-1971, 2003.

60. Stojilkovic SS, Reinhart J and Catt KJ: Gonadotropin-releasing hormone receptors: structure and signal transduction pathways. Endocr Rev 15: 462-499, 1994

61. Shacham S, Harris D, Ben-Shlomo H, Cohen I, Bonfil D, Przedecki F, Lewy H, Ashkenazi IE, Seger R and Naor Z: Mechanism of $\mathrm{GnRH}$ receptor signaling on gonadotropin release and gene expression in pituitary gonadotroph. Vitam Horm 63: $63-90,2001$

62. Halvorson LM, Kaiser UB and Chin WW: The protein kinase C system acts through the early growth response protein 1 to increase LHbeta gene expression in synergy with steroidogenic factor-1. Mol Endocrinol 13: 106-116, 1999.

63. Pirih FQ, Nervina JM, Pham L, Aghaloo T and Tetradis S Parathyroid hormone induces the nuclear orphan receptor NOR-1 in osteoblasts. Biochem Biophys Res Commun 306: 144-150, 2003.

64. Pichon B, Jimenez-Cervantes C, Pirson I, Maenhaut C and Christophe D: Induction of nerve growth factor-induced gene-B (NGFI-B) as an early event in the cyclic adenosine monophosphate response of dog thyrocytes in primary culture. Endocrinology 137: 4691-4698, 1996.

65. Lim RW, Zhu CY and Stringer B: Differential regulation of primary response gene expression in skeletal muscle cells through multiple signal transduction pathways. Biochim Biophys Acta 1266: 91-100, 1995

66. Bondy GP: Phorbol ester, forskolin, and serum induction of a human colon nuclear hormone receptor gene related to the NUR 77/NGFI-B genes. Cell Growth Differ 2: 203-208, 1991.

67. Garcia I, Pipaon C, Alemany S and Perez-Castillo A: Induction of NGFI-B gene expression during T cell activation. Role of protein phosphatases. J Immunol 153: 3417-3425, 1994.

68. Rousseau G, Haddad PS, Gallo-Payet N and Bouvier M $\mathrm{Ca}(2+)$-dependent sensitization of adenylyl cyclase activity. Eur J Pharmacol 422: 53-60, 2001

69. Krsmanovic LZ, Mores N, Navarro CE, Tomic M and Catt KJ: Regulation of $\mathrm{Ca}^{2+}$-sensitive adenylyl cyclase in gonadotropinreleasing hormone neurons. Mol Endocrinol 15: 429-440, 2001

70. Bourguignon JP, Gerard A, Debougnoux G, Rose J and Franchimont P: Pulsatile release of gonadotropin-releasing hormone $(\mathrm{GnRH})$ from the rat hypothalamus in vitro: calcium and glucose dependency and inhibition by superactive GnRH analogs. Endocrinology 121: 993-999, 1987.

71. Hidalgo-Diaz C, Malagon MM, Garcia-Navarro S, Luque RM, Gonzalez de Aguilar JL, Gracia-Navarro F and Castano JP: Role of $\mathrm{Ca}^{2+}$ in the secretory and biosynthetic response of porcine gonadotropes to substance $\mathrm{P}$ and gonadotropin-releasing hormone. Regul Pept 116: 43-52, 2003.

72. Weck J, Fallest PC, Pitt LK and Shupnik MA: Differential gonadotropin-releasing hormone stimulation of rat luteinizing hormone subunit gene transcription by calcium influx and mitogen-activated protein kinase-signaling pathways. Mol Endocrinol 12: 451-457, 1998

73. Vasilyev VV, Pernasetti F, Rosenberg SB, Barsoum MJ, Austin DA, Webster NJ and Mellon PL: Transcriptional activation of the ovine follicle-stimulating hormone-beta gene by gonadotropin-releasing hormone involves multiple signal transduction pathways. Endocrinology 143: 1651-1659, 2002. 
74. Benard O, Naor Z and Seger R: Role of dynamin, Src, and Ras in the protein kinase C-mediated activation of ERK by gonadotropin-releasing hormone. J Biol Chem 276: 4554-4563, 2001.

75. Bonfil D, Chuderland D, Kraus S, Shahbazian D, Friedberg I, Seger R and Naor Z: Extracellular signal-regulated kinase, Jun $\mathrm{N}$-terminal kinase, p38, and c-Src are involved in gonadotropinreleasing hormone-stimulated activity of the glycoprotein hormone follicle-stimulating hormone beta-subunit promoter. Endocrinology 145: 2228-2244, 2004.

76. Wurmbach E, Yuen T, Ebersole BJ and Sealfon SC: Gonadotropin-releasing hormone receptor-coupled gene network organization. J Biol Chem 276: 47195-47201, 2001.

77. McCann SM, Karanth S, Mastronardi CA, Dees WL, Childs G, Miller B, Sower S and Yu WH: Hypothalamic control of gonadotropin secretion. Prog Brain Res 141: 151-164, 2002.

78. Kakar SS, Musgrove LC, Devor DC, Sellers JC and Neill JD: Cloning, sequencing, and expression of human gonadotropin releasing hormone $(\mathrm{GnRH})$ receptor. Biochem Biophys Res Commun 189: 289-295, 1992.

79. Whitelaw PF, Eidne KA, Sellar R, Smyth CD and Hillier SG: Gonadotropin-releasing hormone receptor messenger ribonucleic acid expression in rat ovary. Endocrinology 136: 172-179, 1995.

80. Latouche J, Crumeyrolle-Arias M, Jordan D, Kopp N, Augendre-Ferrante B, Cedard L and Haour F: GnRH receptors in human granulosa cells: anatomical localization and characterization by autoradiographic study. Endocrinology 125: 1739-1741, 1989

81. Peng C, Fan NC, Ligier M, Vaananen J and Leung PC: Expression and regulation of gonadotropin-releasing hormone $(\mathrm{GnRH})$ and $\mathrm{GnRH}$ receptor messenger ribonucleic acids in human granulosa-luteal cells. Endocrinology 135: 1740-1746, 1994.

82. Minaretzis D, Jakubowski M, Mortola JF and Pavlou SN: Gonadotropin-releasing hormone receptor gene expression in human ovary and granulosa-lutein cells. J Clin Endocrinol Metab 80: 430-434, 1995.

83. Limonta P, Moretti RM, Marelli MM and Motta M: The biology of gonadotropin hormone-releasing hormone: role in the control of tumor growth and progression in humans. Front Neuroendocrinol 24: 279-295, 2003.

84. Kang SK, Choi KC, Yang HS and Leung PC: Potential role of gonadotrophin-releasing hormone (GnRH)-I and GnRH-II in the ovary and ovarian cancer. Endocr Relat Cancer 10: 169-177, 2003.
85. Moretti RM, Monagnani Marelli M, van Groeninghen JC, Motta $\mathrm{M}$ and Limonta $\mathrm{P}$ : Inhibitory activity of luteinizing hormone-releasing hormone on tumor growth and progression. Endocr Relat Cancer 10: 161-167, 2003.

86. Irmer G, Burger C, Ortmann O, Schulz KD and Emons G: Expression of luteinizing hormone releasing hormone and its mRNA in human endometrial cancer cell lines. J Clin Endocrinol Metab 79: 916-919, 1994

87. Kakar SS and Jennes L: Expression of gonadotropin-releasing hormone and gonadotropin-releasing hormone receptor mRNAs in various non-reproductive human tissues. Cancer Lett 98: 57-62, 1995.

88. Schally AV, Comaru-Schally AM, Nagy A, Kovacs M, Szepeshazi K, Plonowski A, Varga JL and Halmos G: Hypothalamic hormones and cancer. Front Neuroendocrinol 22: 248-291, 2001

89. Szepeshazi K, Schally AV and Halmos G: LH-RH receptors in human colorectal cancers: unexpected molecular targets for experimental therapy. Int J Oncol 30: 1485-1492, 2007.

90. Gaiser T, Ruschoff J, Schally AV, Keller G and Engel JB: Receptor for luteinizing hormone releasing hormone expressed on melanoma, renal cell carcinoma and non Hodgkin lymphoma can be used for targeted chemotherapy with cytotoxic luteinizing hormone analogues. Verh dtsch Ges Pathol 90: 186-192, 2006.

91. Wang Y, Matsuo H, Kurachi O and Maruo T: Down-regulation of proliferation and up-regulation of apoptosis by gonadotropinreleasing hormone agonist in cultured uterine leiomyoma cells Eur J Endocrinol 146: 447-456, 2002.

92. Grundker $\mathrm{C}$ and Emons G: Role of gonadotropin-releasing hormone $(\mathrm{GnRH})$ in ovarian cancer. Reprod Biol Endocrinol 1: $65,2003$.

93. Chen CL, Cheung LW, Lau MT, Choi JH, Auersperg N, Wang HS, Wong AS and Leung PC: Differential role of gonadotropin-releasing hormone on human ovarian epithelial cancer cell invasion. Endocrine 31: 311-320, 2007.

94. Montagnani Marelli M, Moretti RM, Mai S, Procacci P and Limonta P: Gonadotropin-releasing hormone agonists reduce the migratory and the invasive behavior of androgen-independent prostate cancer cells by interfering with the activity of IGF-1. Int J Oncol 30: 261-271, 2007. 